\title{
THE IMPLEMENTATION OF A BILL OF RIGHTS IN NORTHERN IRELAND
}

\section{Colin Harvey, Professor of Constitutional and Human Rights Law, Department of Law, University of Leeds*}

\section{INTRODUCTION}

The language of rights is a prominent feature of public debate in the United Kingdom (UK) and the Republic of Ireland. Legal change in both states in recent times has included human rights protection. This pattern marks a shift in intensity rather than a complete break. Both were already parties to the European Convention for the Protection of Human Rights and Fundamental Freedoms 1950 (ECHR). ${ }^{1}$ The Convention has dominated discussion of reform, in the UK rather more than the Republic of Ireland. The result is that the Convention figures heavily in legal and political life. This reliance on human rights standards reflects international and European trends also. Human rights norms and institutions are now part of the international and European mainstream.

Few states, communities or individuals will reject human rights outright. Most now accept that rights are a "good thing". This fact, while impressive, does not advance the debate very far. The disagreements of significance now largely involve the contested meaning of human rights norms, issues of compliance and the most effective enforcement mechanisms. With the growing number of standards, implementation in particular has become a central concern of the human rights movement.

Northern Ireland is not a sovereign, independent state. It is, at present, a region of the UK. ${ }^{2}$ Although it has a distinct legal system, law and politics are shaped by broader UK processes. In Northern Ireland, human rights have moved from the margins to the mainstream. ${ }^{3}$ The Belfast Agreement 1998 contained extensive reference to human rights protection. ${ }^{4}$ The Agreement, and the Northern Ireland Act 1998, have provided the framework and foundation for much of the human rights debate in Northern Ireland in the last three years. The current Bill of Rights process owes its existence and legitimacy to the Agreement. The aim of this article is to examine issues of implementation which arise from the Bill of Rights debate in Northern Ireland. It is essential that the Northern Ireland process is located within the

\footnotetext{
* The research for this article was facilitated by a grant from the Social Sciences Small Grants Scheme of the Nuffield Foundation. I would like to acknowledge the research assistance of Beatrice Kasaija.

1 ETS (1950) 5; UKTS (1950) 70.

2 The people of Northern Ireland may, at some future date, vote in a poll to leave the UK and form part of a united Ireland, Northern Ireland Act $1998 \mathrm{~s} 1$ and Sch 1.

3 O'Brien and Mageean, "From the Margins to the Mainstream: Human Rights and the Good Friday Agreement" (1999) 22 Fordham International Law Journal 1499.

4 Harvey and Livingstone, "Human Rights and the Northern Ireland Peace Process" [1999] EHRLR 162.
} 
broader arguments around implementation. ${ }^{5}$ A range of mechanisms are in place at present. The Bill of Rights will supplement these. One objective in this article is to suggest that multiple enforcement mechanisms will be vital for the success of a Bill of Rights. It is a banal point, but a Bill of Rights for Northern Ireland will require suitably rigorous enforcement mechanisms. This article explores implementation with reference to current practice, some comparative examples and proposals being debated in Northern Ireland. The objective is not to provide definitive guidance or advice on the way forward. The intention is to raise questions for further discussion and analysis.

\section{HUMAN RIGHTS PROTECTION IN CONTEXT}

\section{(a) Constitutional change and human rights}

The debate on human rights protection in Northern Ireland is occurring within a wider discussion about constitutional change in the UK and the European Union (EU). ${ }^{6}$ Devolution, for example, raises intriguing questions about the future of human rights protection. ${ }^{7}$ The constitutional reform programme of the Labour government lacks an overarching guiding principle. It is piecemeal and pragmatic. There is no political consensus in the UK about the government driven process of constitutional change. ${ }^{8}$ This may give the judiciary an important role in developing constitutional principles, ${ }^{9}$ but it not apparent that this should be their role (or that it is one they are keen to have). The Bill of Rights process in Northern Ireland thus takes place within the context of unease about the coherence of constitutional reform in the UK. The decision to convene an EU Constitutional Convention to consider the constitutional architecture of that particular Union may prompt some reflection about the state of the UK's constitution. If the EU adopts a "written constitution" then a similar process of constitutional codification may be on the agenda in the UK. For example, the existing constitutional arrangements act as an impediment to some of the expressed

5 "We need something more prosaic: 'implementation, implementation, implementation'. The rigour of a legal regime can help to underpin the values of ethical globalisation. The next phase must be less aspirational, less theoretical and abstract, and more about keeping solemn promises made." Mary Robinson, UN High Commissioner for Human Rights, "Globalisation has to take human rights into account" The Irish Times 22 January 2002.

6 For interesting thoughts on comparisons between the UK and US see O'Connor, "Altered States: Federalism and Devolution at the 'Real' Turn of the Millennium" (2001) 60 Cambridge Law Journal 493, at 502: "Federalism represents a true division of power, whereas devolution is simply a delegation. While each of our countries is a Union, there are two spheres of sovereignty in America, but a single realm in the United Kingdom."

7 In March 2001, the Scottish Justice Minister, Jim Wallace, launched the consultation document Protecting our Rights: A Human Rights Commission for Scotland? (2001). See also Analysis: Protecting our Rights: A Human Rights Commission for Scotland (2001) for an examination of the 70 responses received. The majority supported the idea of a Scottish Human Rights Commission (77\%). The Northern Ireland Human Rights Commission made a submission to this process.

8 Lord Lester of Herne Hill, "Developing Constitutional Principles of Public Law" [2001] PL 684.

9 Ibid. 
goals of the present government. A complicated constitutional picture has emerged in the UK. It is this background which makes the drafting of a Bill of Rights for Northern Ireland such a complex task.

\section{(b) Human Rights, the Belfast Agreement and the Northern Ireland Act 1998}

The Belfast Agreement includes reference to human rights. ${ }^{10}$ The language of the document suggested that human rights protection would assume a central place in the future governance of Northern Ireland. The Declaration of Support provided:

"The tragedies of the past have left a deep and profoundly regrettable legacy of suffering. We must never forget those who have died or been injured, and their families. But we can best honour them through a fresh start, in which we firmly dedicate ourselves to the achievement of reconciliation, tolerance, and mutual trust, and to the protection and vindication of the human rights of all." 11

In Strand One, the ECHR, any Bill of Rights and the Human Rights Commission are included in a list of safeguards "to ensure that all sections of the community can participate and work together successfully in the operation of these institutions". ${ }^{12}$ The stress is on safeguards which will guarantee participation. In other respects, the Northern Ireland Assembly is straightforwardly constrained with reference, for example, to the Human Rights Act 1998..$^{13}$ A provision of an Act of the Assembly is not law if it is incompatible with the relevant provisions of the ECHR. ${ }^{14}$ Mechanisms are in place within the Assembly to scrutinise whether proposed legislation is within its legislative competence. For example, the Presiding Officer ensures that the provisions of proposed legislation are scrutinised prior to their introduction to the Assembly. ${ }^{15}$ The Northern Ireland Human Rights Commission also has a role in offering advice on the compatibility of a Bill with human rights. ${ }^{16}$ The reference to human rights in the relevant provisions of the Northern Ireland Act 1998 is not confined to the ECHR. This allows the Commission to draw upon a range of human rights standards in providing advice to the Assembly.

The relevant Minister is required to state that a new Bill is within the legislative competence of the Assembly. ${ }^{17}$ The Attorney General for Northern Ireland has the power to refer the issue of competence to the Judicial Committee of the Privy Council for decision. ${ }^{18}$ A positive decision on legislative competence from the Judicial Committee applies to the

10 Agreement Reached in the Multi-Party Negotiations (1998, Cm 3883).

11 "Declaration of Support" para 2.

12 Strand One "Democratic Institutions in Northern Ireland" para 5.

13 Strand One "Democratic Institutions in Northern Ireland" para 26(a); Northern Ireland Act 1998 s 6(2)(c) and s 7 (1)(b).

14 Northern Ireland Act 1998 s 6(2)(c).

15 Northern Ireland Act 1998 s 10.

16 Northern Ireland Act 1998 s 69(4).

17 Northern Ireland Act $1998 \mathrm{~s} 9$.

18 Northern Ireland Act 1998 s 11. 
provision if it is enacted as part of an Act of the Assembly. ${ }^{19}$ The Assembly Committees also have a significant role in the legislative process. There is, however, as yet no human rights committee. ${ }^{20}$

The current scheme permits pre-legislative scrutiny with reference to human rights standards, in addition to court-based mechanisms. Democratic mechanisms are therefore in place to assist in mainstreaming human rights. Reference to human rights can be found in the Executive Committee's Programme for Government 2002-2004.21 Initiatives such as New Targeting Social Need are also aimed at securing socio-economic rights, although not explicitly addressed in this language. ${ }^{22}$

Reference to the Bill of Rights is included in the section on "Rights, Safeguards and Equality of Opportunity". On human rights, the parties to the Agreement affirmed the importance of the following rights: the right of free political thought; the right to freedom and expression of religion; the right to pursue democratically national and political aspirations; the right to seek constitutional change by peaceful and legitimate means; the right to freely choose one's place of residence; the right to equal opportunity in all social and economic activity, regardless of class, creed, disability, gender or ethnicity; the right to freedom from sectarian harassment; and the right of women to full and equal political participation. Reference is made, not merely to principles, but also to new institutions. The Northern Ireland Human Rights Commission, formally established under the Northern Ireland Act 1998, is first mentioned in the Agreement. ${ }^{23}$ The creation of the Commission (although not entirely novel in the Northern Ireland context) is recognition of the importance of supplementing traditional forms of human rights protection. This is reinforced when one considers another result of the Belfast Agreement; the creation of the Irish Human Rights Commission. ${ }^{24}$

The Bill of Rights for Northern Ireland is mentioned under the heading "United Kingdom Legislation". The relevant section merits full citation:

19 Northern Ireland Act 1998 s 11(4).

20 See Northern Ireland Human Rights Commission, The Northern Ireland Assembly's Standing Orders and Human Rights Protection (2001). See also Belfast Agreement, Strand One "Democratic Institutions in Northern Ireland" para 11: "The Assembly may appoint a special Committee to examine and report on whether a measure or proposal for legislation is in conformity with equality requirements, including the ECHR/Bill of Rights." There is a Human Rights Unit within the Office of the First Minister and Deputy First Minister. Its aim is: "The promotion of a culture of rights and responsibilities within the Northern Ireland departments and the public authorities for which they are responsible."

21 Northern Ireland Executive, Programme for Government 2002-2004, endorsed by the Northern Ireland Assembly 10 December 2001, p 15: "The core principles and values of equality and human rights are fundamental to our work. We are committed to promoting equality and human rights through strong legislation and effective public policies and strategies, recognising best practice. In this way we seek to assist greater inclusion."

22 Ibid at 10-11.

23 "Rights, Safeguards and Equality of Opportunity" para 5; Northern Ireland Act 1998 ss $69-72$ and Schedule 7. See generally Livingstone, "The Northern Ireland Human Rights Commission" (1999) 22 Fordham International Law Journal 1465.

24 "Rights, Safeguards and Equality of Opportunity" para 9. 
"The new Northern Ireland Human Rights Commission. . . will be invited to consult and to advise on the scope for defining, in Westminster legislation, rights supplementary to those in the European Convention on Human Rights, to reflect the particular circumstances of Northern Ireland, drawing as appropriate on international instruments and experience. These additional rights to reflect the principles of mutual respect for the identity and ethos of both communities and parity of esteem, and - taken together with the ECHR - to constitute a Bill of Rights for Northern Ireland. Among the issues for consideration by the Commission will be:

- the formulation of a general obligation on government and public bodies fully to respect, on the basis of equality of treatment, the identity and ethos of both communities in Northern Ireland; and

- a clear formulation of the rights not to be discriminated against and to equality of opportunity in both the public and private sectors."

The Belfast Agreement provides a new context for considering the protection of human rights in Northern Ireland. Brice Dickson, the Chief Commissioner of the Northern Ireland Human Rights Commission, argues that it is time to flood Northern Ireland with human rights and equality thinking as a way to ensure peace and stability. ${ }^{25}$ There is an ongoing debate about the role of the Commission. The Northern Irish Commission has made a number of proposals to improve its overall effectiveness. ${ }^{26}$ These proposals address some of the problems it has faced.

\section{(c) The Human Rights Act 1998}

Political developments in Britain have had (and for straightforward legal reasons continue to have) an important impact on Northern Ireland. As noted above, Northern Ireland remains part of a unitary state. If a majority of the population decide to vote to leave the UK then they will be joining another unitary state (the Republic of Ireland). The variety of attempts to challenge constitutional orthodoxy have not altered the attachment of the Westminster Parliament to traditional conceptions of sovereignty.

The general election of May 1997 brought a government to power in Britain committed to legislating for human rights. ${ }^{27}$ One result was the enactment of

25 Dickson, "The protection of human rights- lessons from Northern Ireland" [2000] EHRLR 213.

26 Northern Ireland Human Rights Commission, Report to the Secretary of State Required by Section 69(2) of the Northern Ireland Act 1998 (2001).

27 Lord Irvine of Lairg, "Constitutional Reform and a Bill of Rights" [1997] EHRLR 483; Jack Straw (the then Secretary of State for the Home Department) HC Debs vol 307 col 769 (16 February 1998): "This is the first major Bill on human rights for more than 300 years. It will strengthen representative and democratic government. It does so by enabling citizens to challenge more easily actions of the state if they fail to match the standards set by the European Convention. The Bill will thus create a new and better relationship between the Government and the 
the Human Rights Act 1998. ${ }^{28}$ The Act is applicable throughout the UK, and extensive preparations were made for its entry into force. ${ }^{29}$ The legislation has been described, unfortunately ${ }^{30}$ (in my view) on numerous occasions, as a Bill of Rights, ${ }^{31}$ and less problematically as having special constitutional significance. $^{32}$ The legislation, which gives further effect ${ }^{33}$ in the UK to selected Convention rights, has limits. ${ }^{34}$ It is too early to assess the precise impact of the new legislation. ${ }^{35}$ As one would expect, it has been raised in

people." Straw and Boateng, "Bringing Rights Home: Labour's plans to incorporate the European Convention in UK law" [1997] EHRLR 71.

28 Jowell and Cooper (eds), Understanding Human Rights Principles (2001).

29 Croft, "Whitehall and the Human Rights Act 1998" [2001] EHRLR 392.

30 Although "incorporation" of the ECHR has long been described as one way to achieve a Bill of Rights for the UK there are flaws in this approach. While the rights are subject to dynamic interpretation by the European Court of Human Rights, and new Protocols can be adopted, the ECHR has its limitations. There are good reasons to support the notion of "home grown" Bills of Rights which reflect the particular circumstances of specific legal jurisdictions.

31 Klug, Values for a Godless Age: The Story of the United Kingdom's New Bill of Rights (2000) at 20: "But the Human Rights Act is more than just the incorporation of a regional human rights treaty into UK law, which on the face of it could be a relatively minor, technical development. The people of these islands have finally got a bill of rights."

32 Lord Irvine of Lairg, "The Development of Human Rights in Britain under an Incorporated Convention on Human Rights" [1998] PL 221; Clayton and Tomlinson, The Law of Human Rights (2000) at 66; D. Feldman, "The Human Rights Act 1998 and Constitutional Principles" (1999) 19 Legal Studies 165.

33 See the comments of Lord Lester of Herne Hill HL Debs vol 584 cols $1257-1260$ (19 January 1998) and the response of Lord Irvine of Lairg HL Debs vol $584 \mathrm{col}$ 1261 (19 January 1998).

34 McGoldrick, "The United Kingdom's Human Rights Act 1998 in Theory and Practice", (2001) 50 ICLQ 901, at 908: "There was no attempt in the Human Rights Act to add any new substantive rights and there was no adaptation of the ECHR to the UK system. Thus, there is no general right to equality, no inclusion of social rights or economic rights, no express minority rights, and no specific gender based rights."

35 One impact is the significant increase in the use of comparative jurisprudence, see McGoldrick ibid at 919. See Klug and Starmer "'Incorporation through the "front door': the first year of the Human Rights Act" [2001] PL 654, at 664: "[T]here is clear evidence that the Human Rights Act has begun to influence judicial decisionmaking in a broad range of cases." Note also Wadham, "The Human Rights Act: One year on" [2001] EHRLR 620, at 638-639: "Perhaps those who lobbied for the Human Rights Act were a little naïve because despite these more optimistic signs from the courts Liberty does not think that overall the judiciary have followed the principles in the Convention as well as they should. . . As a result of this analysis Liberty is creating a new 'Human Rights Litigation Unit' to assist applicants to take their cases to the Strasbourg Court." See Gearty, "Tort Law and the Human Rights Act" in Campbell, Ewing and Tomkins (eds), Sceptical Essays on Human Rights (2001) at 243-259: "[The Human Rights Act] will be buffeted on the waves of litigation, thrown back and forth between various litigants, sometimes doing good, sometimes doing bad, occasionally being washed up on useless analytical islands where it will be stuck for years on end until a rescue by some tidal wave of fresh thinking, only to be buffeted endlessly in some new direction. The only thing of which we can be sure is that in ten years' time human rights law will be unrecognisable to us today." 
several cases in Northern Ireland. ${ }^{36}$ Some disappointment has been expressed from the perspective of trends in English law. ${ }^{37}$ This may reflect two things. First, the high levels of expectation which were created, and secondly, the lack of popular backing as a result of an inadequate consultative process. As noted above, there also continues to be uncertainty about the evolving constitutional context. The Human Rights Act was not part of a comprehensive constitutional reform project.

There was much debate about the best model for protecting human rights. The enforcement mechanism is of interest for the purpose of this article. A starting point is that the Act does not give further effect to the ECHR in its entirety. ${ }^{38}$ Technically, the Convention has not been incorporated into national law; it has been given further effect. In addition, the enactment of this legislation does not prevent an individual from taking a case to the European Court of Human Rights. The Act contains an interpretative obligation or "rule of construction". ${ }^{39}$ The courts are under an obligation to interpret primary and subordinate legislation "so far as it is possible to do so" compatibly with Convention rights. ${ }^{40}$ As a direct consequence of the continuing importance of the principle of parliamentary supremacy to the Labour government, ${ }^{41}$ a mechanism was created to permit designated courts to rule on the issue of compatibility without having the power to strike down a provision of primary legislation. ${ }^{42}$ The legislation empowers in Northern Ireland the High Court and the Court of Appeal to make a declaration of

36 See eg, Re McCaffery [2001] NI 378 (QBD); Re A [2001] NI 442 (CA); Re Newton (a minor) [2001] NI 115 (QBD); Re Adams [2001] NI 1 (CA); $R$ v Magee [2001] NI 217 (CA); Re Belfast Telegraph Newspapers Limited [2001] NI 178 (CA); Re Tweed [2001] NI 165 (CA); Reavey and others v Century Newspapers Limited and another [2001] NI 187 (QBD); $R$ v Clinton [2001] NI 207 (CA); Re Guidera's Estate [2001] NI 71 (ChD).

37 Wadham, see note 35

38 Human Rights Act 1998 s 1.

39 Rights Brought Home: The Human Rights Bill (1997, Cm 3782) para 2.8.

40 Human Rights Act 1998 s 3(1). Lord Irvine of Lairg HL Debs vol 582 col 1230 (3 November 1997): "Clause 3 provides that legislation, whenever enacted, must as far as possible be read and given effect in a way which is compatible with the Convention rights. This will ensure that, if it is possible to interpret a statute in two ways-one compatible with the Convention and one not-the courts will always choose the interpretation which is compatible. In practice, this will prove a strong form of incorporation." See $R$ v Offen and others [2001] 2 All ER 154; Poplar Housing and Regeneration Community Association Limited v Donoghue [2001] EWCA Civ 595; $R$ v A [2001] 2 WLR 1546; 3 All ER 1.

41 A constitutional principle which the Labour government was keen to support, Lord Irvine of Lairg HL Debs vol 583 col 522 (18 November 1997): "We submit that this scheme is consistent with the sovereignty of Parliament as traditionally understood." See also Jack Straw HC Debs vol 307 col 772 (16 February 1998).

42 Rights Brought Home: The Human Rights Bill para 2.13: "The Government has reached the conclusion that courts should not have the power to set aside primary legislation, past or future, on the ground of incompatibility with the Convention. This conclusion arises from the importance which the Government attaches to Parliamentary sovereignty. In this context, Parliamentary sovereignty means that Parliament is competent to make any law on any matter of its choosing and no court may question the validity of any Act that it passes. In enacting legislation, Parliament is making decisions about important matters of public policy. The authority to make those decisions derives from a democratic mandate." 
incompatibility in relation to a provision of primary legislation and in prescribed cases subordinate legislation also. ${ }^{43}$ In addition, only the higher courts can declare subordinate legislation to be invalid. The Human Rights Act 1998 makes it unlawful for any public authority to act in a way which is incompatible with Convention rights. ${ }^{44}$ For this purpose "public authority" includes a court or tribunal. ${ }^{45}$ The legislation attempts to strike a balance within the context of the UK's constitutional system. ${ }^{46}$ It does not "entrench Convention rights". ${ }^{47}$ The term "dialogue" has been rejected by members of the senior judiciary as a way of capturing the new relationship between the different branches of government. ${ }^{48}$ The Human Rights Act does not give the courts the last word on human rights issues, a position which matches the Labour government's commitment to parliamentary democracy.

The Bill of Rights for Northern Ireland will supplement the ECHR. One question for the Commission is whether to follow the enforcement mechanism in the Human Rights Act 1998.

\section{(d) The Joint Committee on Human Rights}

If human rights are to be adequately protected then more work is required on legislative processes. Those politicians who criticise unelected judges must demonstrate that democratic processes can accord sufficient respect for human rights standards. Reference has been made to the mechanisms within the Northern Ireland Assembly. There has also been relevant reform within the Westminster Parliament. In its White Paper, Rights Brought Home: The Human Rights Bill, the government stated its belief in "a new Parliamentary Committee with functions relating to human rights". ${ }^{49}$ A Joint Committee on Human Rights has been established. It has the following terms of reference:

"To consider:

(a) matters relating to human rights in the United Kingdom (but excluding consideration of individual cases);

(b) proposals for remedial orders, draft remedial orders and remedial orders made under section 10 of and laid under Schedule 2 to the Human Rights Act 1998; and

(c) in respect of draft remedial orders and remedial orders, whether the special attention of the House should be drawn to

43 Human Rights Act 1998 s 4(5)(e). Acts of the Northern Ireland Assembly are defined as subordinate legislation.

44 Human Rights Act 1998 s 6.

45 Human Rights Act 1998 s 6(3)(a).

46 Lord Hoffmann, "Human Rights and the House of Lords" (1999) 62 MLR 159, at 161: "I do not relish the role of a Platonic guardian and I am pleased to live in a society that does not thrust it upon me."

47 McGoldrick, see note 34, p 907: "Obviously then it makes no legal sense to suggest that the Convention rights are "entrenched."

48 Joint Committee on Human Rights - Minutes of Evidence 26 March 2001, HC 332-iii (2000-2001). See the answers of Lord Bingham of Cornhill and Lord Phillips of Worth Matravers. Note, however, the comments of Lord Woolf of Barnes.

49 See note 39 para 3.6. 
them on any of the grounds specified in Standing Order 73

(Joint Committee on Statutory Instruments)."

The Committee is a select committee of both Houses of Parliament. It has the power to require the submission of written evidence and documents, and to examine witnesses. It has the power to make reports to both Houses of Parliament. It is a useful example of a parliamentary mechanism for enhancing consideration of human rights matters. It is still in the early stages of its work. Thus far the Committee has issued several significant reports dealing with legislative proposals. ${ }^{50}$ It is also consulting on the idea of a UK Human Rights Commission.

\section{(e) The Republic of Ireland and all-Ireland human rights protection}

The Belfast Agreement does not simply address Northern Ireland. It has also resulted in legal change in the Republic of Ireland. The constitutional legal systems of the UK and the Republic of Ireland differ in significant respects. The Republic of Ireland has a written constitution and an established tradition of constitutional rights protection. In the Republic of Ireland, the Supreme Court can strike down legislation which is contrary to the Constitution. In addition, a Bill (with some exceptions and limitations) passed by both Houses of the Oireachtas may be referred by the President to the Supreme Court "for a decision on the question as to whether such Bill or any specified provision or provisions of such Bills is or are repugnant to this Constitution or to any provision thereof". ${ }^{51}$ The Constitution also contains provision for a joint petition from the members of Seanad Éireann and Dáil Éireann to the President that the will of the people should be ascertained on a Bill which deals with a matter of particular national importance. ${ }^{52}$

The Agreement provided:

"The Irish Government will also take steps to further strengthen the protection of human rights in its jurisdiction. The Government will, taking account of the work of the AllParty Oireachtas Committee on the Constitution and the Report of the Constitution Review Group, bring forward measures to strengthen and underpin the constitutional protection of human rights. These proposals will draw on the European Convention on Human Rights and other international legal instruments in the field of human rights and the question of the incorporation of the ECHR will be further examined in this context. The measures brought forward will ensure at least an equivalent level of protection of human rights as will pertain in Northern Ireland." 53

In addition, the Irish government committed itself to the creation of a Human Rights Commission with a mandate and remit equivalent to the Northern

50 See $e g$, Joint Committee on Human Rights Reports on the Anti-Terrorism, Crime and Security Bill, $2^{\text {nd }}$ Report HC 372 (2001-2002) and $5^{\text {th }}$ Report (2001-2002).

51 Art. 26.1.

52 Art. 27.

53 "Rights, Safeguards and Equality of Opportunity" para 9. 
Irish Commission. The Agreement provided for a Joint Committee of both Commissions "as a forum for consideration of human rights issues in the island of Ireland." 54 The Committee was formally established in November 2001. The Irish government has therefore also committed itself to enhanced human rights protection. It has taken a number of steps to implement these agreed measures. The Irish Human Rights Commission was formally established in 2001 after some difficulties over the process of appointments. ${ }^{55}$ The legislation to incorporate the ECHR into Irish law has, at time of writing, not been formally enacted. ${ }^{56}$ When it is in force it will function as a "template for fundamental rights protection in both jurisdictions". ${ }^{57}$ The Irish government appears to have adopted a minimalist approach to incorporation. ${ }^{58}$

\section{(f) International and European contexts}

The individual does not have to rely solely on national mechanisms for protecting human rights. A range of other processes exist at the regional and international levels. At these levels different enforcement mechanisms are in place. Detailed legal rules exist to control access. The focus of the international and regional mechanisms is to encourage more effective national human rights protection.

The EU is perhaps of most relevance: not because of its human rights work, but due to the supremacy of EU law. Measures adopted in EU law are of particular significance because of their legal status in the national law of member states. Membership of the EU has transformed the scholarly debate in the UK, particularly with regards to traditional ideas of sovereignty. The UK and the Republic of Ireland are both members of the EU. As the EU becomes a "constitutional entity" so reference to human rights and equality will also increase. This is evident with the adoption of the EU Charter of Fundamental Rights, as well as the equality measures which have been enacted. The suggestion that the EU might craft a formal constitution may have an impact on the human rights debate in the UK.

The Council of Europe is the more obvious focus for human rights lawyers. The European Court of Human Rights is perhaps the best known regional enforcement mechanism. A large number of cases arising from events in Northern Ireland have been processed through the Convention institutions. ${ }^{59}$

54 "Rights, Safeguards and Equality of Opportunity" para 10.

55 Human Rights Commission Act 2000; Human Rights Commission (Amendment) Act 2001.

56 European Convention on Human Rights Bill 2001. For comment see Murphy, "The Incorporation of the European Convention on Human Rights into Irish Domestic Law", [2001] EHRLR 640; O'Connell, "The Irish Constitution and the E.C.H.R.: Belts and Braces or Blinkers?" (2000) Irish Human Rights Review 90.

57 Murphy ibid at 642.

58 Murphy ibid at 642.

59 See eg, McCann v UK (1995) 21 EHRR 97; Brogan v UK (1988) 11 EHRR 117; Brannigan and McBride v UK (1993) 17 EHRR 539; Jordan $\mathrm{v}$ UK judgment of 4 May 2001; McKerr $\mathrm{v}$ UK judgment of 4 May 2001; Shanaghan $\mathrm{v} U K$ judgment of 4 May 2001; Kelly and others v UK judgment of 4 May 2001. 
The right of individual petition is arguably a major reason for its success. Recent cases demonstrate that this mechanism remains important. ${ }^{60}$

The right of petition is reflected in other international mechanisms. In addition, the state reporting mechanism within the UN is relevant, ${ }^{61}$ as is the work of Special Rapporteurs. ${ }^{62}$ There are a variety of other international legal and political mechanisms to assist the protection of human rights. This includes the work of non-governmental organisations (NGOs). The adoption of a Bill of Rights will not alter the ability of the individual to make use of international and regional mechanisms.

\section{PROPOSALS FROM NORTHERN IRELAND}

\section{(a) Consulting on a Bill of Rights}

The debate around a Bill of Rights for Northern Ireland precedes the Belfast Agreement. ${ }^{63}$ Extensive consideration of the subject has already taken place in Northern Ireland. ${ }^{64}$ Earlier research demonstrated wide-ranging political support for a Bill of Rights. ${ }^{65}$ The Belfast Agreement supplies a different context and the document provides the starting point for the current process. Following a request from the Secretary of State, the Northern Ireland Human Rights Commission commenced the Bill of Rights process on 1 March 2000. ${ }^{66}$ The process was prioritised by the Commission. ${ }^{67}$ It consistently

60 Ibid.

61 See Lansdown, "The Reporting Process Under the Convention on the Rights of the Child" in Alston and Crawford (eds), The Future of UN Human Rights Treaty Monitoring (2000) at 113-128; Clapham, "UN Human Rights Reporting Procedures: An NGO Perspective" in the same edited volume at 175-198.

62 For example, see, Report of the Special Rapporteur of the Commission on Human Rights on the Independence of Judges and Lawyers E/CN.4/2001/65 (1 February 2001) paras 213-229.

63 For references to past discussion of a Bill of Rights see Harvey, "The Politics of Rights and Deliberative Democracy: Drafting a Northern Irish Bill of Rights" [2001] EHRLR 48. The work of the Standing Advisory Commission on Human Rights (SACHR) is of particular interest. See generally Boyle and Hadden, Northern Ireland: The Choice (1994) at 181: "The obvious conclusion is that a Bill of Rights for Northern Ireland will have to be specially drafted to meet the particular concerns of all sections of the community. . . The best approach may be to incorporate the terms of the European Convention into a new Northern Ireland Constitution with appropriate additional provisions to satisfy all groups that by agreeing to the compromises necessary for shared government they will not be risking their fundamental interests or aspirations. If the European Convention were incorporated into the law of the United Kingdom and the Republic of Ireland, as argued below, a Northern Ireland Bill of Rights need only contain the additional provisions."

64 See Northern Ireland Human Rights Commission, Making a Bill of Rights for Northern Ireland (2001) at 6: "There is a long history of demands for a Bill of Rights for Northern Ireland and prior to the current peace process there was consensus among the main political parties that a Bill of Rights for Northern Ireland would be a good thing."

65 Committee on the Administration of Justice, Making Rights Count (1990).

66 Northern Ireland Act 1998 s 69(7). The process was launched with events in Derry and Belfast on 1 March 2000.

67 Northern Ireland Human Rights Commission, Annual Report 2001 (2001) at 20. 
stressed the importance of participation. ${ }^{68}$ The consultation process included: training sessions with potential trainers; the production of training videos and trainers' manuals; the publication of explanatory pamphlets; the establishment of nine advisory working groups; and meetings with political parties and interest groups. ${ }^{69}$ The Commission received over 200 written submissions to its initial consultation exercise. ${ }^{70}$ Beyond the Commission an Ad Hoc Human Rights Consortium was established. The Consortium brought together a group of NGOs with the aim of complementing the work of the Human Rights Commission in the promotion of a broad debate. The specific aim of the Consortium was to concentrate on process rather than substance. In other words, the Consortium was not arguing for any particular content but trying to encourage participation.

As noted, the Commission established a number of independent advisory working groups. One of these groups was asked to deal with implementation issues. The Implementation Working Group published its report in January 2001. The Report of this Group is of particular relevance here. In the absence of knowledge of the rights to be included, the Report of the Group concentrated on providing options, rather than specific recommendations. The result was a Report which listed possible approaches, rather than one which advanced one or more specific proposals. The Report thus provides a useful range of implementation options. The Report cited two background trends at the international, regional and national levels of particular significance: the development of overarching rights frameworks; and increased justiciability of socio-economic rights. ${ }^{71}$ The Report then listed a range of questions, which are answered with several options. It raised the following questions:

\section{“ [Implementation Issues]}

- How legislatively could a Bill of Rights 'supplement' the rights already guaranteed by the ECHR?

- How could rights be enforced (and what body/bodies should do it)?

- How should rights be interpreted by the courts and/or other public bodies or state actors?

- How could a broad range of rights be made justiciable, in particular, how could socio-economic rights be made justiciable?

- Should rights cover devolved or also non-devolved issues?

- How should limitations on rights be dealt with?

- How could a Bill of Rights be made into a permanent feature of the legal system of Northern Ireland?

- To whom should a Bill of Rights apply?

68 Ibid.

69 Ibid at 6-7.

70 Northern Ireland Human Rights Commission, Making a Bill of Rights for Northern Ireland (2001) p 9.

71 Ibid, para 2.1. 
- Who can avail of the Bill of Rights ('standing')?

- What remedies should be available to those whose rights are violated?"

This is not the place to describe all the proposed options. A few do merit scrutiny here. The Working Group listed three possible models for the form the new protections might take. First, the Human Rights Act 1998 could be repealed and replaced by a Bill of Rights which would take its place. ${ }^{72}$ The Bill of Rights would be drafted as a single document and include the ECHR and the supplementary rights. Secondly, the enactment of two new pieces of legislation: an amended Human Rights Act 1998, and an additional list of supplementary rights. ${ }^{73}$ Finally, a single statute with supplementary rights with no amendment of the Human Rights Act $1998 .^{74}$ On enforcement, the Working Group listed two possible options. Option one (enforcement by a special Human Rights Court) could apply to either the first or second legislative suggestions. Option two would apply to the final legislative proposal. Although the Human Rights Act 1998 would remain unamended, a new Human Rights Court could be established to address the supplementary rights. In addition, the idea of special assessors was mentioned. On the applicability of the ECHR and supplementary rights, the Working Group was agreed that ideally they should apply to devolved and non-devolved issues.

The working groups formed one part only of the broader consultation process. A number of written submissions contained suggestions on implementation. The Committee on the Administration of Justice (CAJ) argued for a new court to enforce the Bill of Rights, ${ }^{75}$ as did Amnesty International, ${ }^{76}$ and the Social Democratic and Labour Party (SDLP). ${ }^{77}$

Following the initial consultation exercise the Commission published, in September 2001, Making a Bill of Rights for Northern Ireland. ${ }^{78}$ The document contained a range of preliminary views, and in it the Commission presented a large number of questions. On implementation it was evident that much remained to be decided.

In this document the Commission recognised that a Bill of Rights could not do everything:

"It should be remembered, of course, that a Bill of Rights cannot cure all ills. It merely provides a set of minimum standards. The effective protection of rights requires additional rights-based legislation and enforcement mechanisms. Furthermore, the protection of rights often involves a

$72 \mathrm{Ibid}$, paras 4.2-4.5.

73 Ibid, paras 4.6-4.8.

74 Ibid, paras 4.9-4.10.

75 Committee on the Administration of Justice, Preliminary Submission to the Human Rights Commission on a Bill of Rights for Northern Ireland (2001).

76 Amnesty International, Northern Ireland: An Inclusive Bill of Rights for All (2001).

77 Social Democratic and Labour Party, A Bill of Rights for All of Us: Delivering the Good Friday Agreement (2001).

78 See note 70. 
balancing exercise: as well as claiming our own rights we owe a responsibility to allow other people to claim theirs." 79

The Commission concluded that the Human Rights Act 1998 mechanism was also appropriate for the Bill of Rights. ${ }^{80}$ If adopted, this would mean that the same procedures of enforcement would apply. An Act of the Westminster Parliament could still not be struck down. As the Commission noted, no further appeal to the European Court of Human Rights would be available in relation to the supplementary rights. ${ }^{81}$ On possible objections to the Judicial Committee of the Privy Council, the Commission suggested some flexibility in the selection of judicial panels. ${ }^{82}$ Several submissions suggested the establishment of a new court. The Commission was undecided on the issue, and preferred to set out the advantages and disadvantages. Further views were sought. Given the importance of the issue, this section of the document merits citation in full:

\section{"Advantages}

- It could provide for a judicial rights-based culture so as to increase the chances that human rights would be central to the thinking of all judges in all courts.

- It could represent a fresh start to the interpretation and enforcement of the full range of human rights in Northern Ireland and could thus help to bolster general confidence in all sections of the community in the rule of law and remove any doubts some people may have about the attitude of Northern Irish judges when dealing with human rights matters.

- It would facilitate the development of innovative approaches to enforcement, especially as far as social and economic rights are concerned, which judges trained in the traditional system might find difficult.

\section{Disadvantages}

- In some cases it would be difficult to separate human rights issues, which would be the exclusive jurisdiction of the new court, from other issues and there might not be enough work for full-time judges dedicated only to human rights cases.

- It is not clear what the relationship of the judges of the new court would be to those in the ordinary courts and there might be difficulty in establishing the legitimacy of the new system. It could lessen the chances of making human rights central to the thinking of all judges in all courts.

- $\quad$ There would be political and constitutional difficulties in preventing decisions of the new court being subject to

99 Ibid at 6.

80 Ibid at 100 .

81 Ibid at 100

82 Ibid at 100 . 
appeal to the House of Lords and/or the Privy Council and if appeals were permitted some of the alleged advantages of the system would be jeopardised." 83

The Commission also noted another option. In partnership, and as a longterm goal, the Privy Council might become a constitutional court for the UK. ${ }^{84}$ Beyond the Commission's proposal, there is some discussion at present of the idea of a UK constitutional court. ${ }^{85}$ Whichever option was favoured, the Commission argued for the adoption of new procedures for judicial appointments involving a new Judicial Services Commission. ${ }^{86}$ In addition, the Commission supported the idea of advanced review of proposed legislation, referring to the situation in the Republic of Ireland and France. ${ }^{87}$ The Commission also noted the current procedure for the referral of proposed legislation from the Northern Ireland Assembly. ${ }^{88}$

The Commission included a proposed clause on effective remedies. ${ }^{89}$ The clause would permit courts, including lower courts, to develop innovative remedies, particularly in relation to the enforcement of socio-economic rights. ${ }^{90}$ The Commission recognised some potential objections, notably that this would give lower courts an overly broad discretion, and that the contrast with the Human Rights Act 1998 could not be justified. ${ }^{91}$ The issue of referral of cases to a higher court was proposed by the Commission, with the suggestion that a duty should be imposed on magistrates' courts and county courts to refer a case to the High Court "if the decision they propose to take in the case is in their view based on legislation which is incompatible with the Bill of Rights". 92

Who should have standing to bring a case to court under the Bill of Rights? The Commission's preliminary view was that those with a legitimate interest should be able to bring proceedings under the Bill of Rights. ${ }^{93}$

\section{(b) The politics of human rights}

The Northern Ireland Assembly debated the work of the Commission on 25 September 2001. Esmond Birnie of the Ulster Unionist Party (UUP) moved the following motion:

"That this Assembly believes, in the context of the development of a Bill of Rights, that the Northern Ireland Human Rights Commission has failed to discharge its remit, as given to it by the Belfast Agreement 1998, in its various

83 Ibid at 101

84 Ibid at 101-102.

85 Le Sueur and Cornes, The Future of the United Kingdom's Highest Courts (2001); Le Sueur, What is the Future of the Judicial Committee of the Privy Council? (2001).

86 See note 70 p 101.

87 See note $70 \mathrm{p} 104$.

88 See Northern Ireland Act 1998 s 11.

89 See note $70 \mathrm{p} 102$.

90 Ibid, $\mathrm{p} 103$

91 Ibid.

92 Ibid.

93 See note 70, pp 103-104. 
contributions to the debate on developing human rights in Northern Ireland." 94

Birnie, while acknowledging that human rights were a good thing, argued that the Commission had failed to discharge its remit. He addressed the matter of the "particular circumstances of Northern Ireland" in some detail.95 His position on this issue can be summarised as follows: the Commission should have addressed the constitutional question instead of declaring its neutrality on the issue; the particular circumstances of Northern Ireland should include deaths resulting from terrorism and therefore include nonstate violations; and finally, that socio-economic deprivation was not particular to Northern Ireland and not suitable for judicial enforcement. ${ }^{96}$ Birnie was also concerned about "massive social engineering to reconstruct the totality of Northern Ireland", the raised expectations on socio-economic matters and the danger to the new Assembly of a maximalist human rights culture. ${ }^{97}$ An amendment to the motion was put down by Alex Attwood and Patricia Lewsley (SDLP). ${ }^{98}$ Attwood argued in support of the Commission and suggested that its powers and resources might be enhanced. Mary Nelis of Sinn Fein and Eileen Bell of the Alliance Party opposed the motion and supported the amendment. ${ }^{99}$ The debate in the Assembly broadly reflects the views of the political parties on both the Commission and the Bill of Rights process. There was little explicit reference to enforcement of a Bill of Rights. However, Birnie raised some hard questions about the Bill of Rights process. His concern about a maximalist human rights culture reflects an unease among some politicians (not simply in Northern Ireland) about the impact of expansive human rights protections on the democratic process. This is not the last word that the Assembly will have on the matter.

\section{(c) Rights and Responsibilities}

Responses to the document varied. The CAJ, in a highly critical response, suggested that the document was "very confused" and generally lacked "strategy and cohesion". 100 It also criticised the use of the term "rights and responsibilities". ${ }^{101}$

The advice from the Commission to the Secretary of State (whenever it is eventually finalised) will come at a time when there is a distrust of rights-talk among some politicians at Westminster. There is a perception that rightstalk encourages excessive individualism. ${ }^{102}$ The stress now, within the Labour Party in particular, is on rights and responsibilities. As Klug notes:

94 Northern Ireland Assembly, Official Report (2001-2002) 25 September 2001.

95 He also stated: "Note that the agreement said 'advise and consult'. It did not say "campaign and dictate."

96 See note 94.

97 Ibid.

98 Delete all after "Commission" and insert: "has been hindered in discharging its remit due to limits on its powers and resources but congratulates the Commission on its substantial contributions to the debate on and in developing human rights in Northern Ireland."

99 See note 94.

100 CAJ, Submission to the Northern Ireland Human Rights Commission (2001).

101 Ibid.

102 Giddens, Where Now for New Labour? (2002) at 51. 
"Within this overall communitarian perspective Blair gives special emphasis to the idea of duties. "No rights without responsibilities' has become a mantra of New Labour as closely identified with Tony Blair's 'third-way politics' as social inclusion, or modernized public services." 103

Anthony Giddens talks of the construction of a "new social contract" based on the theorem "no rights without responsibilities". ${ }^{104}$ This is viewed now as a key feature of citizenship. But it is difficult to construct all rights in terms of social goods, as Giddens appears to. In addition, what about rights attaching to physical presence on a territory rather than citizenship? Can they easily be constructed as part of a new social contract involving responsibilities too? Is it not better to argue that a person possesses a right (even if she is adjudged to have acted irresponsibly), but there are justifiable limitations to most right? Klug correctly identifies the schizophrenic qualities of the Labour government, with its support for human rights at the international level, but profound distrust of rights-talk in domestic politics. ${ }^{105}$ The suspicion is that the stress on responsibilities will re-surface when the advice of the Commission is submitted to the Secretary of State.

\section{THE BILL OF RIGHTS PROCESS IN COMPARATIVE PERSPECTIVE}

There is extensive comparative experience from which to draw in any debate about a Bill of Rights for Northern Ireland. ${ }^{106}$ Although Northern Ireland is not a sovereign state, this comparative experience is of some use when reflecting on the Bill of Rights process. It is important to remember, however, that each national context differs. For example, the US experience of a Bill of Rights is markedly different from that of Canada or New Zealand. Using the US model to criticise judicial activism has its limitations. The most important enactments since 1945 contemplate the limitation of rights, and do not necessarily give the final word to an unelected judiciary. ${ }^{107}$ In addition, few, if any, advocates of human rights argue that the courtroom should be the exclusive forum for human rights enforcement.

Comparative practice can be used in arguments either for or against the enactment of constitutional rights. In other words, the nature of comparative experience is often disputed. If one takes the example of Canada, there is continuing disagreement about the impact of the Charter of Rights and Freedoms. In addition, there is a politics of comparison. Individuals and groups tend to use examples which enhance or support their pre-existing

103 See note 31 p 59.

104 Giddens, The Third Way and its Critics (2000) 52.

105 Klug, see note 31 p 51.

106 For analysis of current issues in comparative law see Symposium, "New Directions in Comparative Law", (1998) 46 American Journal of Comparative Law 597-756. On the use made by judges of comparative human rights materia see McCrudden, "A Common Law of Human Rights?: Transnational Judicial Conversations on Constitutional Rights", (2000) 20 Oxford Journal of Legal Studies 499.

107 Roach, The Supreme Court on Trial: Judicial Activism or Democratic Dialogue (2001) at 289. 
political positions. Therefore, comparative experience can illustrate ways of doing things which may, or may not, prove useful in crafting local responses. The primary focus should be on constructing human rights protections which work in the particular circumstances of the local jurisdiction, and which reflect the concerns and priorities of the political community. Finally, having a Bill of Rights is no guarantee that rights will be adequately protected. ${ }^{108}$

\section{(a) Canada}

In 1982, the Canadian Constitution was amended to include the Charter of Rights and Freedoms. The Charter was the product of active participation at all levels. ${ }^{109}$ A Special Joint Committee of the Senate and the House of Commons received over 1,200 briefs expressing views. ${ }^{110}$ There were numerous political considerations in the adoption of the Charter. In addition to dissatisfaction with parliamentary politics in Canada, the Charter also had centralising aims at a time when regionalism was on the rise. ${ }^{111}$ At the time, dissent was largely confined to aboriginal groups and political elites in Quebec. ${ }^{112}$ Since its adoption the group of dissenters has expanded.

This was not the first piece of human rights law in Canada. The Bill of Rights 1960 was in force for some time, but was widely regarded as a weak instrument. ${ }^{113}$ The experience with the 1960 Bill of Rights demonstrates that merely having a Bill of Rights (just like simply having a Human Rights Commission) means little unless it has a practical impact on human rights protection.

The Constitution Act 1982 provides that the Constitution of Canada is the supreme law and that any law inconsistent with it is of no force or effect. ${ }^{114}$ The Charter has generated an impassioned debate in Canada. There is continuing argument about the impact it has had on Canadian society, and the power of judicial review. The Charter was widely debated in the UK following the decision of the Labour government to legislate for human rights. ${ }^{115}$ The Charter permits anyone whose "rights or freedoms, as guaranteed by this Charter, have been infringed or denied" to apply to a court "to obtain such remedy as the court considers appropriate and just in the circumstances". ${ }^{116}$ The Charter applies to the Parliament and government of Canada, and to the legislature and government of each province. ${ }^{117}$ The rights and freedoms are subject "only to such reasonable limits prescribed by

108 Amnesty International, Amnesty International Report 2001 (2001).

109 Black-Branch, "Entrenching Human Rights Legislation under Constitutional Law: The Canadian Charter of Rights and Freedoms" [1998] EHRLR 312.

110 Ibid at 322.

111 Fudge, "The Canadian Charter of Rights: Recognition, Redistribution, and the Imperialism of the Courts" in Campbell, Ewing and Tomkins (eds), Sceptical Essays on Human Rights (2001) 335, at 336.

112 Ibid.

113 See note 109 p 317

114 Constitution Act 1982 s 52(1).

115 Rights Brought Home: The Human Rights Bill para 1.13 and para 2.11.

$116 \mathrm{~S} 24(1)$.

117 S 32. 
law as can be demonstrably justified in a free and democratic society". ${ }^{118}$ There is, however, an important exception. The Charter provides:

"Parliament or the legislature of a province may expressly declare in an Act of Parliament or of the legislature, as the case may be, that the Act or provision thereof shall operate notwithstanding a provision included in section 2 or sections 7 to 15 of this Charter." 119

A declaration under this section ceases to have effect five years after it comes into force. ${ }^{120}$ An earlier date may be specified in the declaration. ${ }^{121}$ The Charter is enforced by the courts and ultimately by the Supreme Court of Canada.

David Beatty is critical of the Supreme Court, arguing that the judges appointed to it have not done a good job of protecting basic human rights. ${ }^{122}$ One of the problems, for Beatty, is the way that judges are appointed.

"It puts justice and the values on which the Charter is based at risk when the commitment of those nominated to the Court is ambiguous and clouded in doubt. Indeed, Canada's experience strongly suggests that, in the absence of rigorous questioning of candidates' views about the theory and practice of constitutional law before their appointment, such a risk is almost certain to materialise. . . . For countries considering whether to incorporate a written Bill of Rights into their constitutions, I have no doubt that the single most important lesson to be learned from Canada's experience is that the extent to which human rights are protected in a society depends, more than anything else, on the way judges are appointed to its courts." 123

This highlights the importance of the process of appointment, and the commitment of individuals to human rights protection. Anne Bayefsky echoes this:

"The demands of theory notwithstanding, the Canadian Supreme Court's general retrenchment on Charter review in recent years seems to have had more to do with changes in the Court's membership and particular judicial personalities than principle." 124

On this view, the Supreme Court has not gone far enough. ${ }^{125}$ This increased focus on the judiciary is noted by other commentators. ${ }^{126}$ Writing from the

118 S 1.

119 S 33(1).

120 S 33(3).

121 Ibid.

122 Beatty, "The Canadian Charter of Rights: Lessons and Laments" (1997) 60 MLR 481.

123 Ibid at 497-498.

124 Bayefsky, "Mechanisms for Entrenchment and Protection of a Bill of Rights: The Canadian Experience" [1997] EHRLR 496, at 498.

125 Contrast this with Ison, "The Constitutional Bill of Rights - The Canadian Experience" (1997) 60 MLR 499. He argues that no one really knows the overall 
perspective of a feminist advocate, Mary Eberts concludes that for women the experience of the first years of the Charter has been generally positive. ${ }^{127}$ She is careful, however, to express some caution. She notes, for example, that Charter equality litigation is risky as well as costly. ${ }^{128}$ Risky in the sense that, "the consequences of a decision denying equality under an entrenched Constitution may be severe and long-term". ${ }^{129}$ Roland Penner, in an examination of the arguments of "left-critics", argues that the "experience with the Charter has both generally and specifically advanced the cause of human rights in Canada". ${ }^{130}$ He has no illusions about the role of a Bill of Rights.

"It is my considered view that though a bill of rights cannot be, instrumentally, a sword in the vanguard of transformative politics as urged by some, it can be a shield capable of defending the disempowered, the disadvantaged, the marginalised and the discriminated-against in society in certain, albeit limited, respects. ..."131

A Bill of Rights will protect the marginalised. But it will also shield corporations $^{132}$ and powerful groups in society. Somewhat cynically Ison states:

"About the only groups in society that have clearly benefited from the Charter are constitutional and criminal lawyers, drug traffickers and transnational corporations." 133

Others have observed the potential of the Charter to provoke participation. ${ }^{134}$ Judy Fudge notes a growing dissatisfaction in Canada with the Charter and its impact on political practices and constitutional arrangements. ${ }^{135}$ Perhaps

impact of the Charter, due mainly to the lack of empirical research. He does conclude, however, that the Charter has had a negative impact on human rights proceedings.

126 Sharpe, "The Impact of a Bill of Rights on the Role of the Judiciary: A Canadian Perspective" in Alston (ed), Promoting Human Rights Through Bills of Rights: Comparative Perspectives (1999) 431-453.

127 Eberts, "The Canadian Charter of Rights and Freedoms: A Feminist Perspective" in Alston (ed), Promoting Human Rights Through Bills of Rights: Comparative Perspectives (1999) 241-282.

128 Ibid at 278-279. On the interpretation of s 15(1) of the Charter see Law v Canada (Minister of Employment and Immigration) [1999] 1 SCR 497.

129 See note 127 p 278. For a positive interpretation of developments on equality see Mahoney, "Charter Equality: Has it Delivered?" in Anderson (ed) Rights and Democracy: Essays in UK-Canadian Constitutionalism (1999) 95-122.

130 Penner, "The Canadian Experience with the Charter of Rights: Are there Lessons for the United Kingdom? [1996] PL 104, at 112.

131 Ibid at 113.

132 R.J. R-MacDonald Inc v Canada (A-G) (SCC, 21 September 1995).

133 See note 125 p 511.

134 Dyzenhaus, "The New Positivists" (1989) 39 University of Toronto Law Journal 361 , at 378 "[A] charter that promises not only freedom and justice for all but also equality provides a forum in which consciousness can be raised. Lawyers can aim to raise consciousness and provoke participation by focusing public attention on the way in which society fails to live up to its formally enacted promise."

135 Fudge, see note 111. 
as a result of this, and other criticism, the Canadian Supreme Court has talked more of partnership with government in recent years. ${ }^{136}$

Human rights protection in Canada is not confined to the Charter or the Supreme Court. Canada also has a Human Rights Commission. ${ }^{137}$ This Commission has the power to refer cases to the Canadian Human Rights Tribunal. The Charter is located in a context where legislative protection of human rights also exists. In addition, the Supreme Court is not the only body charged with human rights implementation and enforcement.

\section{(b) The Republic of Ireland}

Reference has already been made in this article to the Republic of Ireland. It has a written constitution. ${ }^{138}$ This constitution contains express recognition of rights. ${ }^{139}$ The all-Ireland dimensions of the Belfast Agreement give this context a rather different significance from the others considered here. Views differ about the effectiveness of the constitutional protection of rights in the Republic. Weaknesses have been identified. ${ }^{140}$ The ruling of the Irish Supreme Court in Sinnott v Minister for Education ${ }^{141}$ illustrates the distinction sometimes drawn between rights which derive from the constitution and legislative protection.

As noted, the Belfast Agreement has had an impact on the human rights debate in the Republic of Ireland. There is now an Irish Human Rights Commission and the ECHR is being incorporated into domestic law. Prior to this there was a significant process of constitutional reflection embodied in the work of the Constitution Review Group ${ }^{142}$ and carried on by the All-Party Oireachtas Committee on the Constitution. ${ }^{143}$

\section{(c) New Zealand}

New Zealand was cited as an appropriate example for the UK to follow. There are instructive lessons in the decision of the Labour government to adopt this approach. Not everyone agreed that this was appropriate. Unlike Canada, Australia and South Africa, New Zealand does not have a written constitution. Parliamentary supremacy is at the heart the system. This might explain why the UK government was, in particular, attracted to this model of

136 Ibid at 338.

137 See Canadian Human Rights Act 1977 Part II.

138 For the historical background to the 1937 Constitution see Lee, Ireland 19121985: Politics and Society (1989) at 201-211.

139 Arts. 40-44, these are not, however, the only human rights protections in the Constitution. See generally Casey, Constitutional Law in Ireland $\left(3^{\text {rd }}\right.$ ed 2000$)$ chs 12-19.

140 Twomey, "Freedom of Expression - Talking about the Troubles" in Murphy and Twomey (eds), Ireland's Evolving Constitution 1937-1997: Collected Essays (1998) 199-218.

141 [2001] IESC 39, judgment of 12 July 2001.

142 Constitution Review Group, Report of the Constitution Review Group (1996). The All-Party Oireachtas Committee on the Constitution was established in 1996.

143 For example, see, First Progress Report (1997) and Fourth Progress Report: The Courts and the Judiciary (1999). 
human rights protection. ${ }^{144}$ The New Zealand Bill of Rights Act 1990 grew from the 1985 document A Bill of Rights for New Zealand: A White Paper. ${ }^{145}$ There was a negative public reaction to the idea of a Bill of Rights as supreme law, particularly to the notion of unelected judges deciding major issues of public policy. ${ }^{146}$ There was no groundswell of public support for the proposals. Suspicion existed (similar to that which exists in the British Labour Party) within the New Zealand Labour Party about the judicial branch. ${ }^{147}$ Political support, even for the weakened proposals, was based on the particular circumstances of New Zealand. ${ }^{148}$ As a result, the New Zealand Bill of Rights Bill was introduced to Parliament in October 1989. A provision was inserted (section 4) to assert and preserve parliamentary sovereignty. ${ }^{149}$ The Act contains an interpretative obligation:

"Wherever an enactment can be given a meaning that is consistent with the rights and freedoms contained in this Bill of Rights, that meaning shall be preferred to any other meaning." 150

No new judicial body was created. The New Zealand example was described as a bad one for the UK to follow. ${ }^{151}$ Nevertheless, Michael Taggart argues that the Act has significantly altered legal culture and discourse in New Zealand. ${ }^{152}$ The problems the Act presented the judiciary with are also worth noting. ${ }^{153}$ These difficulties did not, however, prevent some judges from

144 It may be instructive for those engaged in the Northern Irish Bill of Rights process to note this attachment to New Zealand practice. In other words, when faced with a choice over which model to follow the Labour government opted for the "minimalism" of the New Zealand example.

145 See Joseph, "The New Zealand Bill of Rights Experience" in Alston (ed), Promoting Human Rights Through Bills of Rights: Comparative Perspectives (1999) 283-317.

146 Allan, "The Effect of a Statutory Bill of Rights where Parliament is Sovereign: The Lesson from New Zealand" in Campbell, Ewing and Tomkins (eds), Sceptical Essays on Human Rights (2001) 375-390.

147 Taggart, “Tugging on Superman's Cape: Lessons from Experience with the New Zealand Bill of Rights Act 1990" [1988] PL 266, at 267.

148 The period of government led by Sir Robert Muldoon persuaded many of the need for a Bill of Rights, Taggart ibid. Note the comment of Joseph, see note 145 p 283, on the proposed Bill: "It was a partisan measure promoted with the support of the (then) National Opposition, or of most Government members, and with little public interest." Joseph notes, however, that in practice the Act has worked well.

149 See Final Report of the Justice and Law Reform Select Committee on a White Paper for a Bill of Rights for New Zealand (Appendices to the Journal of the House of Representatives I.8C, 1988); Butler, "The Bill of Rights Debate: Why the New Zealand Bill of Rights Act 1990 is a Bad Model for Britain" (1997) 17 OJLS 323, at 324.

150 Bill of Rights Act 1990 s 6. See Butler, "Interface between the Human Rights Act 1998 and other enactments: pointers from New Zealand" [2001] EHRLR 249.

151 Emmerson, "This Year's Model-The Options for Incorporation", [1997] EHRLR 313. Cf Lord Irvine of Lairg, "Activism and Restraint: Human Rights and the Interpretative Process" [1999] EHRLR 350.

152 Taggart, see note 147 p 287. Cf Lord Cooke of Thorndon HL Debs 583 cols 533534 (18 November 1997).

153 Joseph, see note 145 p 317. 
trying to "upgrade" the legislation. ${ }^{154}$ The experience of New Zealand suggests that even a relatively weak instrument, with little popular support, can still make a contribution to human rights protection. ${ }^{155}$

\section{(d) South Africa}

Developments in South Africa provide a useful example of an expansive Bill of Rights, adopted within the context of a broader constitutional settlement. The constitutional settlement was marked by an intensive process of participation. The Constitution of South Africa 1996 is the supreme law of the Republic. ${ }^{156}$ This extensive process (springing from human rights abuses on a different scale to those in the UK) stands in marked contrast to the timid constitutional reform project of the Labour government. ${ }^{157}$ The Bill of Rights is one part of the new constitutional order in South Africa. As Arthur Chaskalson states:

"The new constitutional order was given legitimacy, which in view of its origin it might not otherwise have had, when the interim Constitution was replaced by a new Constitution adopted by an elected Constitutional Assembly consisting of the two houses of Parliament sitting together. The Constitution thus adopted is based on respect for human rights and democracy. It spells out the values on which the new constitutional order has been established. They include human dignity, the achievement of equality and the advancement of human rights and freedoms." 158

The Bill of Rights is contained in Chapter 2 of the Constitution of the Republic of South African 1996. The purpose of the Bill of Rights is stated concisely:

"This Bill of Rights is a cornerstone of democracy in South Africa. It enshrines the rights of all people in our country and affirms the democratic values of human dignity, equality and freedom." 159

The state must "respect, protect, promote and fulfil the rights contained in the Bill of Rights". ${ }^{160}$ If any law or conduct is inconsistent with the Bill of

154 Allan, see note 146 p 379 and p 390 . He suggests that one lesson from New Zealand is that we can expect judges to upgrade and retool their statutory model.

155 The Bill of Rights Act 1990 is not the only relevant matter. New Zealand also has a national Human Rights Commission.

$156 \mathrm{~S} 2$.

157 Jagwanth, "The South African Experience of Judicial Rights Discourse: A Critical Appraisal" in Campbell, Ewing and Tomkins (eds), Sceptical Essays on Human Rights (2001) 297-314.

158 Chaskalson "Judging Human Rights in South Africa" [1998] EHRLR 181, at 182.

159 S 7(1).

160 S 7(2). Christian Education South Africa v Minister of Education (SACC 18 August 2000), per Sachs J: "It should be noted that these rights to be violencefree are additional to and not substitutes for the right not to be punished in a cruel, inhuman or degrading way. Under section 7(2) the state is obliged to 'respect, protect, promote and fulfil' these rights. It must accordingly take appropriate steps to reduce violence in public and private life. Coupled with its special duty 
Rights the courts are required to declare it invalid to the extent of such inconsistency. ${ }^{161}$ On a constitutional matter the courts may "make any order that is just and equitable". ${ }^{162}$

There is a general limitations clause. ${ }^{163}$ The Bill of Rights applies to all law in South Africa and binds the legislature, the executive, the judiciary and all organs of the state. ${ }^{164}$ It also binds a natural or a juristic person "if, and to the extent that, it is applicable, taking into account the nature of the right and the nature of any duty imposed by the right". ${ }^{165}$ The Bill of Rights contains standing rules which include anyone acting in the public interest, and an association acting in the interests of its members. ${ }^{166}$ It also includes interpretative guidance to courts and tribunals. ${ }^{167}$ They are required to: promote "the values that underlie an open and democratic society based on human dignity, equality and freedom", ${ }^{168}$ and consider international law. ${ }^{169}$ They may consider foreign law. ${ }^{170}$ In addition:

"When interpreting any legislation, and when developing the common law or customary law, every court, tribunal or forum must promote the spirit, purport and objects of the Bill of Rights." 171

Debate about the justiciability of socio-economic rights has been settled in South Africa. ${ }^{172}$ Provision is made for socio-economic rights. ${ }^{173}$ The Bill of Rights contains a right to housing, health care, food, water and social security. ${ }^{174}$ The state is under an obligation to "take reasonable legislative and other measures, within its available resources, to achieve the progressive realisation of each of these rights". ${ }^{175}$

towards children, this obligation represents a powerful requirement on the state to act."

$161 \mathrm{~S}$ 172(1)(a).

162 S 172(1)(b)

163 S 36.

164 S 8(1).

165 S 8(2)-(4).

$166 \mathrm{~S} 38$.

167 S 39(1).

168 S 39(1)(a).

169 S 39(1)(b)

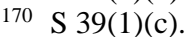

171 S 39(2).

172 In re Certification of the Constitution of the Republic of South Africa 19961996 (10) BCLR 1253: "It is true that the inclusion of socio-economic rights may result in the court making orders which have implications for budgetary matters. However, even when a court enforces civil and political rights such as equality, freedom of speech or the right to a fair trial, the order it makes will often have such implications. . . In our view it cannot be said that by including socioeconomic rights within a Bill of Rights, a task is conferred upon the courts so different from that ordinarily conferred upon them that it results in a breach of the separation of powers. . We are of the view that these rights are to some extent justiciable."

173 Ss 26-27.

174 Ibid.

175 S 26(2) and s 27(2). The Government of the Republic of South Africa v Grootboom and others, (SACC 4 October 2000) per Yacoob J para 24: "The right 
Unlike Canada, a new Constitutional Court was created. ${ }^{176}$ It was established in 1994 under the interim Constitution. ${ }^{177}$ The Court has 11 members and is the highest court in South Africa with respect to constitutional matters. ${ }^{178}$ Its decisions bind all other courts. ${ }^{179}$

"The Constitutional Court

a. is the highest court in all constitutional matters;

b. may decide only constitutional matters, and issues connected with decisions on constitutional matters; and

c. makes the final decision whether a matter is a constitutional matter or whether an issue is connected with a decision on a constitutional matter." 180

The Court makes the final decision on whether an Act of Parliament, a provincial Act or conduct of the President is constitutional. ${ }^{181}$ In order to address concerns about judicial appointments a Judicial Services Commission was established. ${ }^{182}$ Saras Jagwanth argues that the Constitutional Court has contributed "sporadic achievements" to social transformation in South Africa. ${ }^{183}$ She points to the central role of the democratic process in fleshing out the rights protected in the Constitution. ${ }^{184}$ In other words, the importance of progressive legislation to the transformation of South Africa. A number of Commissions were also created: Human Rights Commission; ${ }^{185}$ Commission for the Promotion and Protection of the Rights of Cultural, Religious and Linguistic Communities; ${ }^{186}$ and a Commission for Gender Equality. ${ }^{187}$ These are included under the heading of "state institutions supporting constitutional democracy" as three of the six such bodies. ${ }^{188}$

of access to adequate housing cannot be seen in isolation. There is a close relationship between it and other socio-economic rights. Socio-economic rights must all be read together in the setting of the Constitution as a whole. The state is obliged to take positive action to meet the needs of those living in extreme conditions of poverty, homelessness or intolerable housing. Their interconnectedness needs to be taken into account in interpreting the socioeconomic rights, and, in particular, in determining whether the state has met its obligations under them."

176 See Chaskalson, see note 158 p 190: "One of the paradoxes of the new constitutional order is that courts, which were previously used to enforce apartheid and the repression associated with it, have now been given a central role in giving substance to the new democratic order."

177 See Spitz with Chaskalson, The Politics of Transition: A Hidden History of South Africa's Negotiated Settlement (2000) at ch 11.

178 S 167.

179 See s 165(1): "The judicial authority of the Republic is vested in the courts."

180 S 167(3)

$181 \mathrm{~S} 167(5)$.

182 S 178.

183 Jagwanth, see note 157 p 314.

184 Ibid.

185 S 184.

186 Ss $185-186$.

187 Ss 187.

188 Ch 9. 


\section{DELIVERING A NORTHERN IRISH BILL OF RIGHTS}

\section{(a) Addressing the Belfast Agreement}

The final section of this article contains some general thoughts on the Bill of Rights process. The advice has not as yet been submitted to the Secretary of State. Given the fundamental significance of a Bill of Rights it is wise to make sure that sufficient thought is given to it.

As stated earlier, Northern Ireland is not a sovereign state. While devolution has promoted local democracy, and generated a debate about federalism, this is still within the context of a unitary state. This constitutional background shapes both the use of comparative material and proposals advanced for a Bill of Rights.

The Bill of Rights process operates under a specific legal mandate. This mandate is contained in the Belfast Agreement. It is from the Agreement that the process gains its legitimacy. While it is accurate to argue that the Commission possesses a general remit to advance proposals for human rights protection, it will be difficult to make this case to the Secretary of State. The Commission must fulfil the Agreement's mandate if it is to gain acceptance for its proposals in Northern Ireland. The relevant passage of the Agreement is ambiguous in parts, but there are concrete references to matters which should be included. These matters may require the Commission to be innovative. For example, in areas where the Agreement goes beyond international standards.

There are understandable reasons why consensus, stability and agreement are stressed as essential in Northern Ireland. When the legacy of political violence remains alive the stress is correctly placed on consensus and stability. A Bill of Rights will in the longer term assist this process. However, it is essential that this does not undermine the role of disagreement in a democracy. A Bill of Rights will generate impassioned argument and continuing disagreement. This is what democratic politics is about. It is therefore unwise to leave the impression that a Bill of Rights will only promote harmony in Northern Ireland. Disagreement and dissent will be another product.

\section{(b) The process of making a Bill of Rights}

The Commission has stressed the participative nature of the Bill of Rights process. It has attempted, within the constraints of its resources and powers, to encourage a wide-ranging debate. Beyond the Commission other initiatives have been launched by human rights groups. The process of securing consensus around a set of coherent proposals is central to effective enforcement. Judges, politicians and administrators are more likely to accord sufficient weight to this legal instrument if it is seen to have widespread popular backing across all communities in Northern Ireland. There is disagreement about how effective the Commission's work has been. Questions can legitimately be raised about the merit of entrusting the Bill of Rights process to a newly established Human Rights Commission. The Commission is in its early stages of development. The decision to grant the Commission (at such an early stage) the exclusive right to advance advice on a Bill of Rights to the Secretary of State may come to be regarded as a 
flawed approach. If process is essential to effective enforcement then questions can fairly be raised about what has taken place in Northern Ireland. The process would appear not to have generated the level of engagement or consensus one would expect. The danger at this stage is that the Commission may be unable to deliver coherent proposals for a Bill of Rights which have widespread support in Northern Ireland.

\section{(c) The Interdependence of all human rights}

All human rights (civil, political, economic, social and cultural) are interdependent. Socio-economic rights are recognised as justiciable rights, although the obligation on the state tends to be couched in the language of progressive realisation. In this context, there is nothing in international law to prevent the inclusion of a broad range of human rights. Innovative enforcement mechanisms may need to be crafted for socio-economic rights, but this is not a reason for their exclusion. The debate in Northern Ireland has turned on minimalist or maximalist interpretations of the Belfast Agreement. Focusing on the "particular circumstances of Northern Ireland" some argue for a Bill of Rights which concentrates on accommodating the communal rights of the two main communities. Thus a Bill of Rights, in this interpretation, would contain reference to parity of esteem, the protection of national aspirations and the cross-community partnership arrangements found in the Belfast Agreement. Others argue for a more generous interpretation of the Agreement's mandate which could assist in building bridges between communities in Northern Ireland. On this interpretation, an expansive Bill of Rights is merited.

The Commission has committed itself to proposing the best possible Bill of Rights for Northern Ireland. The problem is that severe disagreement exists both inside and outside of the Commission. This is not motivated by bad faith. Rather there are genuinely divergent views on the nature and scope of this process and the substantive issues addressed.

What legal form should the Bill of Rights take? Proposals to repeal the Human Rights Act and replace it with a Bill of Rights (Northern Ireland) Act seem, at first sight, to be highly problematic. However, this approach has much to recommend it. A single, unified legal document would have the advantage of clarity and could assist the task of mainstreaming the rights it contains. Those who are committed to mainstreaming human rights should be able to see merit in this approach.

\section{(d) A multiplicity of enforcement mechanisms}

Few human rights advocates argue that the courtroom is the only forum for protecting rights. There is general recognition that rights must be mainstreamed in the process of governance. This could not be achieved if everything was left exclusively in the hands of the judiciary. To suggest that human rights lawyers wish simply to enhance the power of unelected judges is a serious mistake. A Bill of Rights for Northern Ireland will have to reflect a commitment to mainstreaming rights. This will only be achieved by building human rights principles into processes of public administration.

There will be disagreement after the enactment of a Bill of Rights and some individuals and groups will not approve of the political and legal culture 
which will emerge. Disagreement, rather than consensus, is a normal part of life in liberal democracies. ${ }^{189}$ In fact, constitutional systems (inspired by republican thinking in particular) generally acknowledge conflict. ${ }^{190}$ This is not conflict in the sense of political violence, but conflict as a continuing conversation. This is precisely what a functioning democratic polity should set in motion. For republicans, the point is to accept this disagreement and set up a constitutional system which forces engagement. ${ }^{191}$ It is from this engagement that agreement on a particular issue might be attained. A Bill of Rights for Northern Ireland will have to form an important part of this continuing dialogue on good governance. It is a mistake (although a common one) in this context to regard human rights and political democracy as necessarily in conflict. Human rights are in fact, as the South African Constitution acknowledges, central to constitutional democracy.

The challenge for the Human Rights Commission is to generate sufficient consensus around its proposals. The Bill of Rights must be viewed as an instrument crafted to meet local, Northern Irish concerns, rather than as an unpopular imposition.

\section{(e) A new Human Rights Court for Northern Ireland?}

The debate in legal scholarship over the role of the judiciary in a democracy shows no sign of abating. If a Bill of Rights for Northern Ireland is enacted this debate will go on, and even intensify. Experience from elsewhere suggests that disagreement will continue. Some will argue against the enhanced role of unelected judges, others will argue that the judges have not gone far enough in particular cases. In the political sphere, some politicians will become frustrated with what they see as an obstacle to their plans. When criminal justice is transferred to the Northern Ireland Assembly, then, as in other states, some may even begin to view the Bill of Rights as a "rogue's charter". There may even be a backlash against the Bill of Rights from those individuals and groups critical of the new human rights culture. Social conservatives and communitarians frequently voice concerns about rights-talk. Academics will write books and articles about the role of the judges under the Bill of Rights. Some will be constructively critical of the courts, others will lament the dominance of unelected judges. All these disagreements and arguments will be reasonable, and most will be in good faith. Political disagreement will not vanish once a Bill of Rights is enacted.

One issue of central importance is whether a new judicial body is required. Whatever the answer to this question, it is generally accepted that judicial appointment procedures need to be reformed. Continuing education and training is also recognised as important. In my view, proposals for a new Human Rights Court should form part of the final advice of the Human Rights Commission. This Court will fit into the new picture of human rights protection in Northern Ireland, and assist in the process of shaping good governance. It could, for example, view its role as one of partnership with

189 Waldron, Law and Disagreement (1999).

190 Bellamy, "Constitutive Citizenship versus Constitutional Rights: Republican Reflections on the EU Charter and the Human Rights Act" Campbell, Ewing and Tomkins (eds), Sceptical Essays on Human Rights (2001) 15-39.

191 Ibid. 
the existing democratic institutions. The advantages outweigh the disadvantages. The new Court could assist the process of mainstreaming human rights, rather than act as an impediment to this process. In a context where distrust of the judiciary is a fact, a new Court could begin to dispel concerns. It would give a fresh impetus to human rights protection in Northern Ireland, and facilitate the effective enforcement of the Bill of Rights. The new body could craft creative approaches to the enforcement of rights. Much of this will depend, as comparative experience suggests, on processes of appointment and the commitment of the new Human Rights Court to the effective protection of human rights. In addition, to function properly there will have to be standing rules which permit effective access.

As suggested earlier, simply having a Bill of Rights, a Human Rights Commission or even a Human Rights Court is not a reliable guide to how human rights are in practice protected. The creation of a human rights culture will depend on multiple enforcement mechanisms aimed at mainstreaming human rights protection in the governance of Northern Ireland.

\section{CONCLUSION}

Consulting and advising on a Bill of Rights is complex and difficult. The Northern Ireland Human Rights Commission was given a daunting challenge at a time when it was still trying to establish itself. It has made a genuine effort to encourage a debate. It is now reasonable to question the wisdom of entrusting a Bill of Rights process exclusively to a Human Rights Commission which is in its early stages of development. This decision was taken in the negotiations around the Belfast Agreement, and was one way to deal with disagreement on the issue. A similar strategy was adopted for policing and criminal justice. A process like this is aimed at making substantive progress without negating the genuine political disagreements which exist. Leaving the process to a newly formed Commission may have been astute in the context of political negotiations, but was rather unfair on this new body. It is clear that the Commission has been presented with a formidable task.

This article does little more than raise questions about the implementation of a Bill of Rights. The suggestion is that several enforcement mechanisms are required if the common aim is to mainstream the Bill of Rights. These should include building respect for rights into the educational system at all levels, making rights count within the democratic process, and mainstreaming rights in public administration. A Bill of Rights will provide general guarantees. These protections can be enhanced and developed by specific legislation. The key is to ensure that effective co-ordination takes place to assist in the common goal of creating a human rights culture in Northern Ireland. A multiplicity of mechanisms and strategies will be essential to the achievement of this aim. 